\title{
BLAST INJURY OF THE SPINAL CORD
}

\author{
By Lionel Wolman, M.A., M.D., Ph.D., M.R.C.P., F.C.Path., D.P.M. \\ Department of Neuropathology, Royal Infirmary, Sheffield, 6
}

THE opportunity of examining the spinal cord after a blast injury due to high explosives rarely arises. Among persons most close to an explosion the injuries sustained are usually multiple and severe, resulting in immediate death. If less close, survival for a short time commonly occurs and in these the wounds and injuries may also be multiple although in some no overt damage can be recognised. Such a case was described by Mott (1916) where death occurred in a soldier two days after being buried as a result of an explosion. Excavation was effected within five minutes of the burial and no gross injuries, fractures or dislocations could be found. A diffuse sieve-like vacuolisation of myelin fibres with swollen axis cylinders was found in the posterior columns of the lower cervical cord from $\mathrm{C}_{4}-7$. Unilateral cavitation of the grey matter of both anterior and posterior horns in the fifth cervical segment had also occurred. In many cases where no visible injury was recognised and the patient survived, the ensuing symptoms have been attributed to functional neuroses and psychoses. The gradual amelioration of complaints with the passage of time tended to confirm the diagnosis and made the chances of post-mortem examination of the spinal cord remote. It is, therefore, considered of value and interest to record the histological findings in such a case surviving 43 years after injury.

\section{CASE Report}

Male. Born I890. History; At Passchendaele in 1917 he was wounded, sustaining a shell blast injury, as a result of which he suffered from paralysis in both legs for a period of about 18 months followed by steady improvement. A 20 per cent Disability Pension was awarded for this injury which was labelled as 'shell shock with neurasthenia' in 1920. His earlier documents were not available having been destroyed by enemy action. He apparently made sufficient recovery to continue in the Regular Army until I92I when he was transferred to the Reserve. In September 1939 he was recalled from the Territorial Army Reserve of Officers and served throughout World War II on the Home Front. Between 1953 and 1956 he commanded a Battalion of Home Guard until it was disbanded. He had walked with a slight limp in the right leg for at least 20 years and probably longer. The right foot tended to turn inwards. He had required no medical attention till 1956 when repair of a right strangulated inguinal hernia was carried out together with orchidectomy.

In 1959 he developed a sudden attack of dizziness and vomiting followed by collapse. He became unconscious for about 15 minutes. It was noticed that he had a right-sided facial weakness with some twitching of the facial muscles. The power in the limbs was equal as were the reflexes. The right plantar response was flexor and the left extensor. His B.P. was $130 / 85$. He made an uneventful recovery in hospital and was allowed home after 4 days. In November, I960, he was re-admitted with acute retention of urine and a prostatectomy was performed. He complained of weakness of the legs during the convalescent period and they became fixed in flexion. He developed a terminal lung infection and died five weeks after operation, aged 70. 
Post Mortem Examination. The body was that of a well nourished old man, $5 \mathrm{ft} .9$ in. in height. The lower midline abdominal wound had healed satisfactorily. Both thighs and calves showed wasting. Small superficial bedsores were present over each hip. In the lungs both lower lobes and the left upper lobe showed bronchopneumonia which was the immediate cause of death. There was moderate coronary atheroma. The bladder wall was hypertrophied and its mucosa was acutely inflamed. An ascending kidney infection had occurred and there was bilateral pyelitis with a solitary cortical abscess, $2 \mathrm{~cm}$. in diameter in the right kidney. The skull and vertebral column were normal with no indication of any past injury and no narrowing of the spinal canal. The brain appeared normal macroscopically with only slight atheroma of its vessels and no evidence of any infarct. Routine sections of the brain examined microscopically showed no softening. The increased gliosis of the surface of the cortex, of the subependymal tissue and of the walls of perivascular spaces was consistent with the age of the patient.

Examination of Spinal Cord. No macroscopic abnormality was noted during removal or after fixation. Microscopic sections were examined from each segmental level,

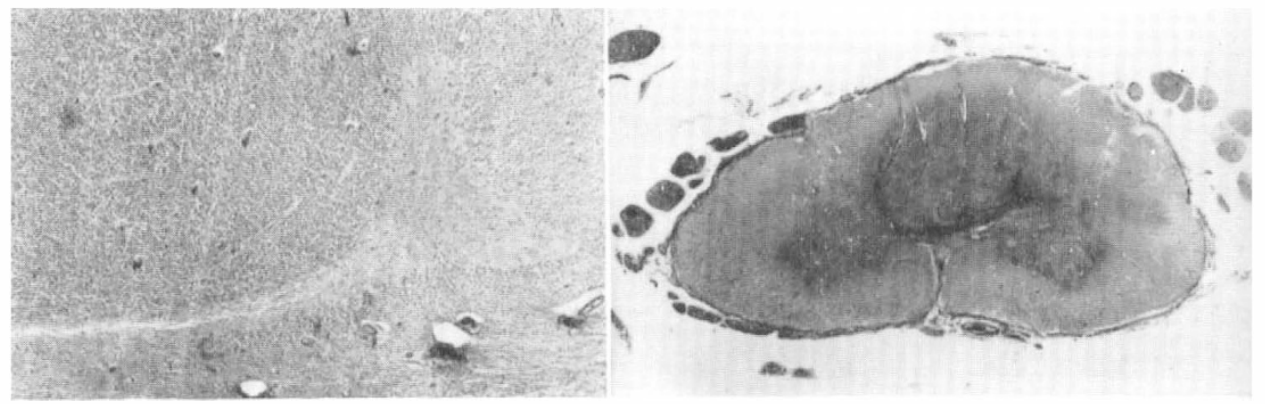

FIG. I

FIG. 2

Figure I-Ventral part of right posterior columns at C8 showing transversely elongated slit with complete loss of nerve fibres in surrounding tissue which is densely gliosed. (Holmes' Silver, $\times 55$.)

Figure 2-Transverse section at C8 showing in the ventral part of the right posterior columns an elongated area of very dense gliosis enclosing a looser acellular glial network in which is a slit-like cavity. (Mallory's P.T.A.H., $\times 7$.)

utilising Haematoxylin and Eosin, Nissl, Weigert's Myelin, Holmes' Silver, Masson's Trichrome and Holzer stains. Frozen sections were employed where appropriate.

The maximal damage to the cord was found in the lower cervical segments. At C8 there was a transversely elongated slit-like cavity (Fig. I), surrounded by dense gliosis especially at its lateral extremities (Fig. 2), situated in the ventral part of the right posterior columns and extending into the midline. The affected area was sharply demarcated from the surrounding tissue, being completely devoid of axis cylinders and myelin sheaths. Scattered corpora amylacea were present round its periphery (Fig. 3). Only scanty astrocytic nuclei were recognised amongst the dense glial network. Patchy areas of demyelination with replacement gliosis were seen in the posterior columns and dorsal part of the lateral columns, more marked on the right side (Fig. 4). At $\mathrm{C}_{7}$ the gliotic lesion extended across the midline dorsal to the central canal into the ventral part of the left medial posterior column (Fig. 5). The denseness of the gliosis and the absence of cellular reaction indicated its long duration. No haemosiderin could be recognised in sections stained for iron. 
Above the site of maximal damage there was ascending degeneration in the deeper part of the posterior columns with scattered small areas of demyelination extending to the dorsal surface and in the dorsal part of the lateral columns as high as $\mathrm{C}_{4}$. Similar areas extended down to the level of $\mathrm{D}_{5}$ below which there was descending degeneration of the cortico-spinal tracts in the lateral columns, worse on the right.

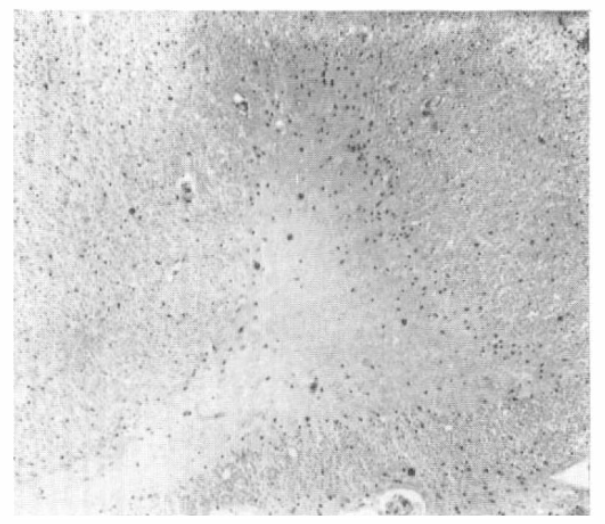

FIG. 3

Scattered corpora amylacea round periphery of gliosed acellular area in ventral part of right lateral posterior column at C8 (Haematoxylin and Eosin, $\times 90$.)

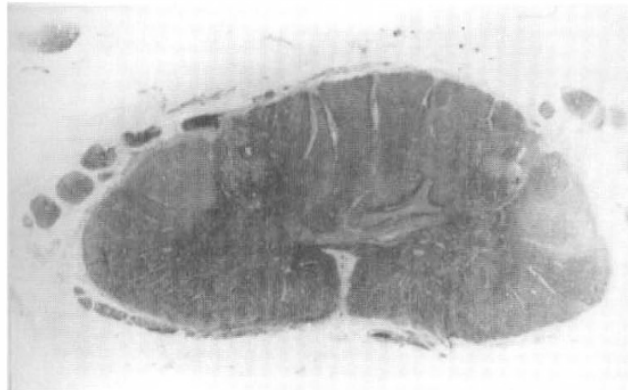

FIG. 4

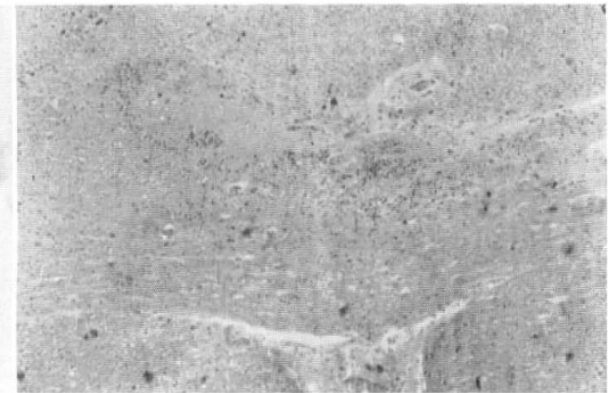

FIG. 5

Figure 4-Transverse section at C8 showing unilateral circumscribed area of demyelination in the ventral part of the posterior columns with scattered areas of less severe demyelination in the adjacent white matter and in the lateral columns especially on the right. (Myelin, $\times 7$.)

Figure 5-Acellular area of gliosis extending bilaterally just dorsal to the central canal at $\mathrm{C}_{7}$. The pia arachnoid of the ventromedian fissure is included in the lower part of the field. (Haematoxylin and Eosin, $\times 55$.)

Several of the dorsal and ventral nerve roots of the cauda equina showed more recent degeneration. Free fat was present in the nerve roots in frozen sections and there was a cellular reaction consisting of foci of lymphocytes and histiocytes. Although no thrombosed vessels were seen in the nerve roots available for examination many of the vasa nervorum showed marked thickening of their walls with minute lumen. As no other cause was found in the spine or pelvis, it seemed likely that the nerve root 
demyelination was of ischaemic origin, possibly secondary to even more severe damage in the more peripheral parts of the nerve fibres.

\section{DISCUSSION}

A blast injury was defined by Clemedsen (1956) as the generic name for the biophysical and pathophysical events and the clinical syndrome and pathologicoanatomical changes caused by exposure of a living body to the effects of a detonating high explosive or to a shock wave generated in some other way. Although such pressure waves exert their maximal effects on gas-containing organs such as the ears, lungs and intestines, solid viscera such as the myocardium, brain and spinal cord, where there are no compressible elements, may contain lesions, such as multiple scattered haemorrhages.

Thus the effects on the central nervous system were reported by Claude and Lhermitte (1915). Petechial haemorrhages were found in the brain and spinal cord of many animals exposed to explosives by Marinesco (I9I8). Small subpial haemorrhages in the spinal cord and nerve roots of rabbits exposed to explosives in the air were described by Mairet and Durante (1919). In the animals studied experimentally by Krohn et al. (1942) haemorrhage was found in the spinal cord in three in relation to cervical fractures.

In humans haemorrhages in the brain and spinal cord have been described by Mott (1917) and Zuckerman (194I). Of the three cases reported by Mott (I9I7) one sustained a superficial graze over the spine of the left scapula, a small 'in and out' wound of the right gluteal region and a complete paralysis of the legs and abdominal muscles with a sensory level at the umbilicus. Death ensued seven days later and the spinal cord showed subarachnoid haemorrhage from D8-L2. The surface veins were congested, some had ruptured and intraradicular haemorrhage was seen. Minute haemorrhages were present in the grey matter of the anterior horns and near the base of the posterior horns adjacent to the central canal. Haemorrhage in the brain or meninges has been more frequently recorded (Abbott et al., I943; Ascroft, I943; Tunbridge \& Wilson, 1943; Rogers, 1945; Cramer et al., 1949). A variety of neurological abnormalities, including xanthochromic cerebrospinal fluid in one case, was recorded by Stewart et al. (I94I) in a small series of cases exposed to blast.

Concerning the mechanism of production of these lesions in the cord, Guillain (I920), as a result of experience in World War I, thought that they were caused by sudden changes in air pressure. Subsequent experience in World War II (Fulton, I942; Latner, I942; Friedell \& Ecklung, I943; Davison, I945) suggested that the forcible throwing to the ground or bruising by earth or masonry which accompany the blast of an explosion could be predominating factors in causation and might even result in subluxation of the cervical spine. That damage to the spinal cord in the neck in the absence of fractures or dislocations of the vertebral column can occur in hyperextension injuries was emphasised by Taylor (I95I), whilst Roaf (I960) pointed out that in the cervical region subluxation with spontaneous reduction can be produced by rotation.

Thus although the haemorrhagic lesions in the spinal cord have been attributed to the back pressure on veins caused by thoracic compression or to air embolus which is known to occur from the pulmonary alveolar damage, the restricted site and distribution of lesions in the present case would not support 
either of these mechanisms. Denny-Brown (1945) has pointed out that if such a condition as concussion from an explosive force alone is to be established it is absolutely necessary to have full documentation of cases where all possibility of secondary injury is absent. No such cases are on record. If, however, the blast wave is considered to have three main effects as described by de Candole (1967) consisting of:

I. Primary due to direct impact on the tissue of pressure variations,

2. Secondary due to flying glass or other debris set in motion,

3. Tertiary due to propulsion of the body,

then the spinal cord lesions can be interpreted as tertiary effects due to the sudden accelerating and decelerating movements similar to those seen in road traffic accidents. Blast by itself has little or no direct effect on the spinal cord (Greenfield \& Russell, I963).

The changes found in this spinal cord, after a survival of 43 years, consisting of a transversely elongated gliosed area in the ventral part of the posterior columns with small scattered gliosed foci in the posterior and lateral columns of the adjacent segments, resemble in distribution those seen in contusion of long duration, although no iron from old haemosiderin could be demonstrated in the lesions after so long a period.

\section{SUMMARY}

A case of blast injury of the spinal cord with a survival of 43 years is reported. Although both legs were paralysed initially a good recovery occurred after i 8 months, apart from a residual limp. No evidence of any fracture of the spine was found but in the lower cervical spinal cord was a transversely elongated slit surrounded by dense gliosis situated in the ventral part of the posterior columns. This lesion together with the small scattered foci of gliosis in the adjacent posterior and lateral columns would be more consistent with an old contusion from being thrown to the ground rather than being due to the direct effect of sudden changes in air pressure.

\section{ACKNOWLEDGMENTS}

My thanks are due to M. R. E. Swanwick, Esq., M.A., H.M. Coroner For The Hundred Of Scarsdale, for permission to publish this case and for supplying many details of the history. I also wish to thank Dr M. A. Lecutier who performed the autopsy for sending me the material for examination together with the full report of his findings.

\section{RÉSUMÉ}

Le cas d'une survie de 43 ans après atteinte médullaire causée par un souffle explosif est rapporté. Malgré une paraplégie initiale une bonne récupération s'est effectuée après I8 mois à part une claudication résiduelle. Aucune évidence de fracture de la colonne vertébrale n'a été retrouvée mais au niveau de la moëlle cervicale basse une fente allongée transversalement entourée d'une gliose dense a été retrouvée au niveau de la partie ventrale des colonnes postérieures. Cette lésion s'accompagnant de petits foyers de gliose au niveau des colonnes postérieures et latérales, serait plus en rapport avec une contusion ancienne du fait de la chute plutôt que celle de l'atteinte directe par la variation des pressions de l'air dûes au souffle. 


\section{ZUSAMMENFASSUNG}

Ein Fall von Explosionsschädigung des Rückenmarks mit einer Überlebenszeit von 43 Jahren wird beschrieben. Obwohl zunächst eine Lähmung beider Beine bestand, gute Wiederherstellung erfolgte, abgeschen von residualem Hinken. Keine Wirbelfraktur wurde gefunden, dagegen aber ein transversal verlaufender Spalt in der Zervikalregion des Markes, umgeben von dichter Gliose im ventralen Teil des Hinterstranges. Diese Läsion, die auch mit vereinzelten gliotischen Herden in den benachbarten Hinter-und Seitensträngen einherging, ist wohl mehr auf eine alte Kontusion durch einen Fall auf den Boden zurückzuführen als auf eine plötzliche Veränderung des Luftdrucks.

\section{REFERENCES}

Aвbott, W. D., Due, F. O. \& Nosik, W. A. (1943). F. Am. med. Ass. I2 I, 664.

AsCROFT, P. B. (1943). Lancet, I, 234.

Claude, H. \& Lhermitte, J. (I9I 5). Annls Méd. 2, 479.

Clemedsen, C.-J. (1956). Physiol.Rev. 36, 336.

Cramer, F., Paster, S. \& Stephenson, C. (I949). Archs Neurol. Psychiat. (Chicago), 6 I, I. Davison, C. (1945). Proc. Ass. Res. nerv. ment. Dis. 24, 85.

De Candole, C. A. (1967). Can. med. Ass. F. 96, 207.

Denny-Brown, D. (I945). Physiol. Rev. 25, 296.

FRIEDELL, M. T. \& ECKLUNG, A. M. (I943). U.S. Nav. med. Bull. 4I, 353.

Fulton, J. F. (1942). New Engl. F. Med. 226, I.

GreEnfield, J. G., \& Russell, D. S. (I963). In Greenfield's Neuropathy, ed. by

Blackwood, W., McMenemey, W. H., Meyer, A., Norman, R. M. \& Russell, D. S., and Edit., p. 46r. London: Edward Arnold.

Guillain, G. (I920). Travaux Neurologiques de Guerre, p. 307. Paris: Masson.

Krohn, P. L., Whitteridge, D. \& ZuCKerman, S. (1942). Lancet, I, 252.

LATNER, A. L. (1942). Lancet. 2, 303.

Mairet, A. \& Durante, G. (I9I9). Revue neurol. 26, 97.

MARINESCO, G. (I9I8). Revue neurol. 25, 329.

MotT, F. W. (I9I6). Lancet, I, 33I, 44I, 545.

Motт, F. W. (I917. Fl. R. Army med. Cps, 29, 662.

ROAF, R. (1960). f. Bone ft. Surg. 42B, 8 Io.

Rogers, L. (1945). Med. F. Aust. 2, 209.

Stewart, C. W., Russel, C. K. \& CONE, W. V. (I94I). Lancet, I, I72.

TAYlOR, A. R. (I95I). F. Bone ft. Surg. 33B, 543.

Tunbridge, R. E. \& Wilson, J. V. (I943). q. Fl. Med. I2, I69.

Zuckerman, S. (194I). Proc. R. Soc. Med. 34, I7I. 